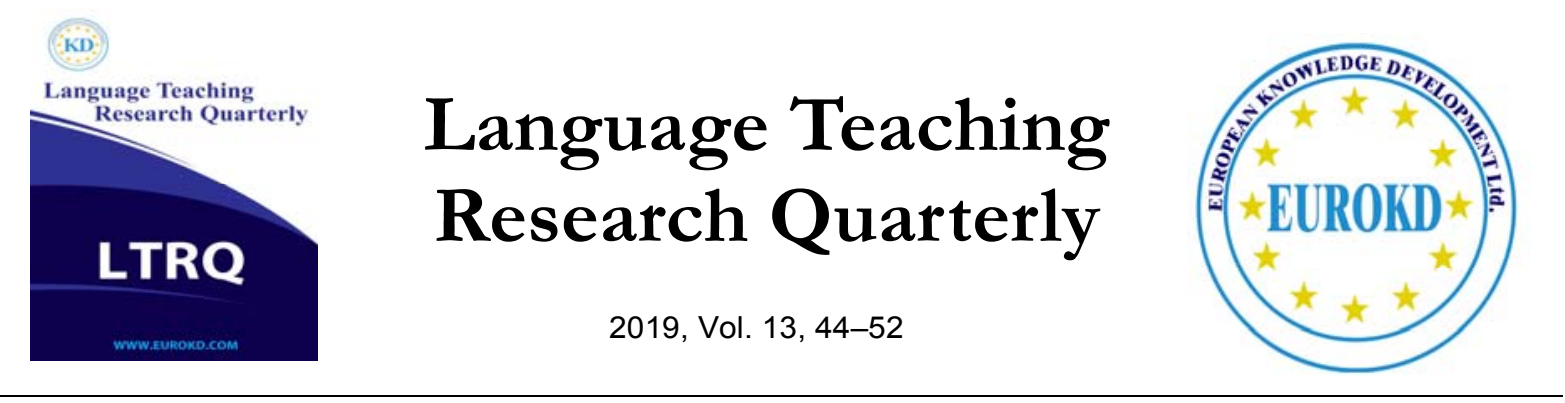

\title{
Pre-Service Teachers' Perception on their EFL Competence and Professional Requirements
}

\author{
Ana María Ramos- García ${ }^{1, *}$, Ana Fernández- Viciana² \\ ${ }^{1}$ Dpto. de Didáctica de la Lengua y la Literatura, Facultad de Ciencias de la Educación, Universidad \\ de Granada. Spain \\ ${ }^{2}$ Facultad Padre Ossó, Universidad de Oviedo, Spain
}

\begin{abstract}
Received 10 June $2019 \quad$ Accepted 05 September 2019

Language teaching and teaching through language have undergone a standardization process all over Europe. In the Spanish context, a myriad of programs has emerged in the last ten years whose main aim is to guarantee a plurilingual education. That means implementing and consolidating European directives on the matter from the Council of Europe. Universities have joined this trend in their need for internationalization. This contribution analyses pre-service teachers' perceptions on their English Foreign Language level and the professional requirements regarding language competence in the current context in which language is a key aspect in education at any level. In spite of the fact that most students $(95.5 \%)$ consider that a language teacher should master the language (C1 CEFR level or at least B2), some of them (19.3\%) acknowledge not having any language accreditation yet, and most are in between B1 and B2 (70\%). Therefore, there is a lack of consistency between their real language level and their perception of what is needed in order to be a successful primary education language teacher. Unquestioningly, their desired level is above their real competence, that is the reason why they plan to continue their English studies once they finish their university degree.
\end{abstract}

Keywords: Pre-Service Education, English Language Level, Life-Long Learning, Motivation

\section{Introduction}

The importance addressed to languages nowadays at any social level is undeniable, and it is a key factor in the labour market. The Council of Europe has been working on the improvement of language learning; has made a considerable effort in the simplification of directives regarding language learning in Europe (Cáceres, 2007) and has promoted many different proposals in order 
to guarantee equal opportunities and foster mobility for any European citizen ${ }^{1}$. The celebration of the European Year of Languages (2001) fostered by the Council of Europe, European Union, and UNESCO drew the attention to language learning in order to cater for individual and social development. At the same time, the Common European Framework of Reference for Languages: Learning, Teaching, Assessment (CEFR) was launched, and has proved to be a successful tool in the teaching and learning of languages across Europe and beyond. The CEFR has provoked a change in the understanding of language learning and/or teaching at any educational level and besides, and at social level. The language level scale has spread widely and the fact that languages are tested in terms of ability — what an individual is able to do in one language - has turned languages into living objects of study (Cáceres, 2007; García Santa-Cecilia, 2002). Its aims are the following (Council of Europe, 2018): (a) "promote and facilitate co-operation among educational institutions in different countries", (b) "provide a sound basis for the mutual recognition of language qualifications"; and (c) "assist learners, teachers, course designers, examining bodies and educational administrators to situate and co-ordinate their efforts" (p.25).

In 2018, there was a sequel of the former framework: Common European Framework of Reference for Languages: Learning, Teaching, Assessment. Companion Volume with New Descriptors. Its aim is to foster the right to an inclusive quality education for all (Council of Europe, 2018). The reference levels have been updated and modified (there is a pre-A1 level and some $\mathrm{C} 1$ and $\mathrm{C} 2$ descriptors have been improved), and there are new descriptors for areas such as mediation and online interaction, as well as plurilingual and pluricultural competence and sign language (Cores, 2017).

Both documents together with many other directives are examples of the work which has been being done at the Council of Europe in favour of language learning. Another European project which is indirectly related to the learning of languages in general to guarantee equal opportunities for any European citizen is the European Higher Education Area (EHEA) which was started (1998) at Sorbonne University after a meeting celebrated by the delegates from four different countries. Its main aim was to adapt higher education to the current needs for professionals in everyday life in a changing and global world. The idea was to respect cultural diversity in each country by standardising those criteria governing higher education in the hope of favouring student and staff mobility, fostering not only language learning - at least two different languages apart from mother tongue - but also the use of Information and Communication Technologies (ICT). However, it was the concept of lifelong learning - a professional's personal responsibility to develop autonomous learning and updating in timewhich has caused more struggle among higher education institutions, as methodological implications have arisen. Degrees have been transformed and adapted in such a way that can be

\footnotetext{
${ }^{1}$ The European Centre for Modern Languages (ECML) is an institution whose mission is to foster excellence and innovation in language teaching and learning, helping Europeans to learn languages more efficiently (https://www.ecml.at/).
} 
described and compared without any problem among the different countries ${ }^{2}$, achieving certain collective and cooperative quality assurance (Ramos, 2008).

All those measures have caused a deep impact on higher education organisation in some countries, such as Spain. Training is now focused on practice in order to cater for social and labour market demands. But the most visible change for the people is the structure which has been adopted $(4+1)$ : four years for undergraduate studies and one for masters. Students benefit from a better personal development being in charge of their learning process by means of active methodologies which help them acquire different strategies in order to guarantee their lifelong learning and lecturers are transformed in a "guide to the side".

In Spain, the adaptation to the EHEA in terms of degrees related to English foreign language teaching in the primary school was developed by the national quality assurance agency (ANECA: Agencia Nacional de Evaluación de la Calidad y Acreditación). This agency presented a plan for the undergraduate studies in Early Childhood Education and Primary Education that universities accepted following the recommendations given by the Ministry of Education and Science. Those degrees last for four years and once pre-service teachers are at the last half of their studies, they can choose the specialisation track they wish among: Special Education, Physical Education, Musical Education, or Foreign Language (English or French) and some other possibilities designed by universities, such as the one devoted to general foundation subjects (ANECA, 2005: vol.1, 42). Also, the Ministry of Education and Science accepted this generalist proposal, as opposed to the specialist one that existed with the old plans of studies, but it established that the pre-service teachers should finish their teaching preparation with a B1 level according to the CEFR (Ministerio de Educación y Ciencia, 2007). However, in the Seminar on bilingual education organised by the University of Alcalá and the British Council among other considerations, it was pointed out the low level of the pre-service teachers who finish their studies within these new university plans (Jover, Fleta y González, 2016). Some other administrations demand teachers to have a higher proficiency in the target language. However, bilingual education has set the level in $\mathrm{C} 1$ in most communities in order to access the programme but there is an adaptation period in which teachers with lower levels may participate reaching the compromise to improve their language level in time.

This is the new scenario in which higher education is being developed, a global world with instant access to new content and new social requirements which are quite demanding on the effective use of languages on the part of graduate students ready to access the labour market. The authors presume — based both on years of personal experience and literature - there is usually a gap between most students' real language level and the one they should achieve in order to carry out their duties as professionals successfully. Therefore, this paper analyses primary education students' perceptions on their English foreign language level and its adequacy to the professional

\footnotetext{
${ }^{2}$ Thanks to the Diploma Supplement, an official document which describes competencies acquired by graduates along their studies in, at least, two different languages.
} 
requirements in the current European context in general and in the Spanish move towards bilingual education in particular.

\section{Methods}

This study was carried out in three Spanish universities. The Spanish university system reorganised its study plans according to the EHEA in 2010. This reorganisation implied the rearrangement of alldegree programmes, including those which qualify graduates to teach in primary education. The degree programmes offer several specialisation tracks and one of them allows students to specialise in teaching English as a foreign language in primary education. Students choose their specialisation track in the $3^{\text {rd }}$ and $4^{\text {th }}$ year or only in the $4^{\text {th }}$ year, depending on each university regulations when organising the study plan. The number of credits in this track varies according to each university programme. However, the credit range goes from 30 to 36 ECTS credits including teaching placement, which are distributed among linguistic and didactic subjects.

This paper pursues the following research objectives:

1) to know the level of English linguistic competence of a group of pre-service English teachers;

2) to gather information about their desired English linguistic competence;

3) to compare those with the professional requirements regarding their linguistic competence.

The study sample consisted of 135 subjects: one hundred women $(74.1 \%)$ and thirty-five men (25.9\%), (see Figure 1). These students took the specialisation track in English foreign language in primary education in the academic year 2018/19.

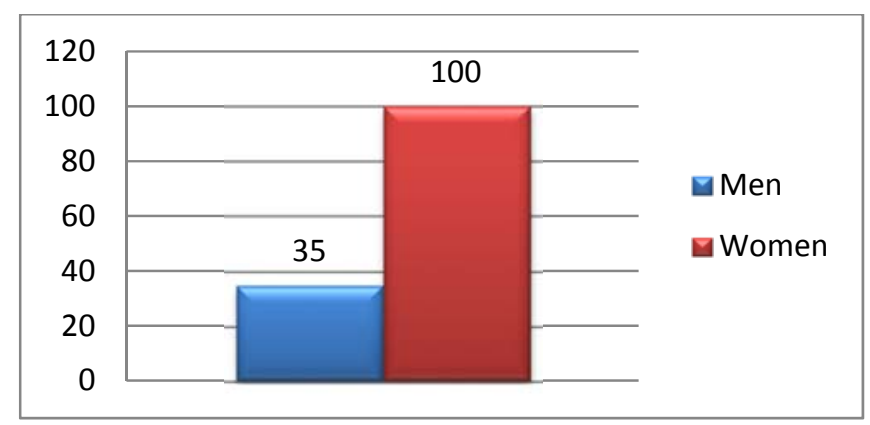

Figure 1. Gender

The research follows a quantitative methodology. Participants were given a survey, which was administered online to facilitate access (Google Drive: http://bit.ly/2F77P0g) and voluntary participation of the informants was guaranteed. The tool was validated by four experts in English foreign language teaching. Then, a final validation was carried out through a pilot study with a group of students with similar characteristics to the research sample. Data was analysed with SPSS v.24. Descriptive statistics (frequency and percentages), as well as Spearman's rho were performed. 
The ad hoc survey formed by a total of 33 items was responded by the participants through multiple choice, yes/no, open-ended questions. The items were classified into four sections: 1) personal data; 2) certified level of English; 3) desirable level of English for a primary English teacher; 4) beliefs about English language training. From the total number of items, this research focuses on five since they are the most relevant for the study.

\section{Results and Discussion}

The first objective of this study is to determine the level of the English linguistic competence of the sample. Our results confirm that the English level of this group of pre-service teachers does not respond to the requirements of the current policies. Only $42.2 \%$ of the sample hold a B2 or higher, whereas the competence of the language of $58.8 \%$ is not high enough. In terms of participants' accreditation according to the different levels established by the CERF (Ministerio de Cultura, Educación y Deporte, 2002) 80.8\% have obtained one. The distribution can be seen in Table 1.

Table 1

Accredited level of English (frequency \& percentage)

\begin{tabular}{ccccccc}
\hline & A2 & B1 & B2 & C1 & C2 & None \\
\hline \multirow{2}{*}{ Total } & 4 & 48 & 46 & 10 & 1 & 26 \\
& $(3)$ & $(35.6)$ & $(34.1)$ & $(7.4)$ & $(0.7)$ & $(19.3)$ \\
\hline
\end{tabular}

It is important to highlight that most of the participants $(69.7 \%)$ have accreditations that correspond to the levels B1/B2. Surprisingly, the higher the level of English is, the lower the percentages are. The distribution among $\mathrm{B} 2, \mathrm{C} 1$, and $\mathrm{C} 2$ - the professional required levelcomprises a $42.2 \%$ of the sample. Therefore, there is a $57.8 \%$ who do not reach the required minimum level in order to perform their everyday chores as language teachers. It is remarkable that $19.3 \%$ do not have any accreditation. These data show that students are far from reaching the C1 level that the Comprehensive Programme on Foreign language learning 2010-2020 (Ministerio de Educación, 2011) establishes as the level required to teach English.

Likewise, these pre-service teachers are aware of the level demanded by schools. On the one hand, English has been included in the curriculum of Early Childhood Education and it is taught from age 3; on the other hand, schools offer bilingual programmes where teachers use the CLIL approach in order to teach subjects such a Science, Arts and Crafts, or Physical Education in English. Language teaching and teaching through language have undergone a standardization process not only in Spain but also all over Europe. In the Spanish context, there have emerged many different programmes in the last decade whose main aim is to foster a better language and/or plurilingual education at any level from Kindergarten to Higher Education.

Therefore, a high competence in English is required to work as an English teacher in these programmes. Furthermore, the number of schools that offer bilingual programmes has increased enormously since 2005. From the implementation of CLIL programmes in schools onwards, 
proficient English teachers are required, and the Ministry of Education and Science has been offering specific training programmes for those teachers who do not achieve the competence in the language needed (Ruiz, 2016). CLIL programmes pursue to hire language users both confident and competent in the target language who are able at the same time to teach their subject content in another language (Mearns, 2012: 176).

Paradoxically, the new primary education undergraduate studies with a specialisation track in English language teaching have restricted the number of credits devoted to linguistic subjects compared to the preceding ones, which were three years and not four. Therefore, pre-service teachers who finish their undergraduate studies do not achieve the adequate linguistic competence as they themselves show in their answers in the questionnaire (Table 2).

Table 2

Desirable linguistic competence (frequency \& percentage)

\begin{tabular}{cccccc}
\hline & A2 & B1 & B2 & C1 & C2 \\
\hline \multirow{2}{*}{ Total } & 1 & 4 & 79 & 50 & 1 \\
& $(0.7)$ & $(3.0)$ & $(58.5)$ & $(37.0)$ & $(0.7)$ \\
\hline
\end{tabular}

The $95.5 \%$ of the participants consider that the desirable level should be B2 or C1. We can affirm that the former is considerably superior to the real linguistic competence in the L2. For this reason, $91.9 \%$ of the sample (124) continues studying English by their own means. However, 8.1\% (11) does not study English (see Figure 2).

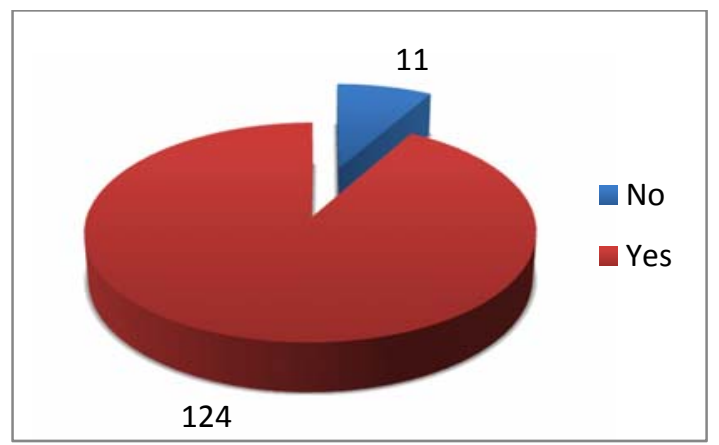

Figure 2. Studying English at the moment

We consider that this problem would be solved if the English specialisation track required a B1 pre-requisite entrance level. Once students are in the programme, the linguistic subjects will take them to a level $\mathrm{C} 1$, which should be the exit level for undergraduates who wish to become English teachers in the primary current educational system in Spain. Consequently, they will achieve the linguistic requirements established by the Ministry of Education and Science.

Spearman's correlation coefficient (rho) confirms the statistical relationship between the variables: a) desirable linguistic competence, and b) accredited linguistic competence. There is a significant correlation between both variables. Although the correlation between both variables is positive, the coefficient of correlation is medium-low $(\rho=.35, \rho<.001)$. 
Informants are conscious that their linguistic competence does not correspond to the demands of the primary schools, so $91.2 \%$ continue studying English. The preferred modalities for studying English (either in language schools or on their own) have already been analysed and commented in a similar study (Fernández-Viciana, Barrios \& Ramos-García, 2019 in press).

At this point it is important to highlight the motivation of the sample to choose this English foreign language track (Figure 3). On the one side, most of the participants, $4.84 \%$, affirm that they like English. On the other side, $4.59 \%$ state that this track offers better job opportunities. The reason "I am good at English" is just considered by $4.16 \%$ of the respondents. These results show that the competence in the language is not considered as a key factor in order to choose this specialisation track, even when participants are aware of the schools demands.

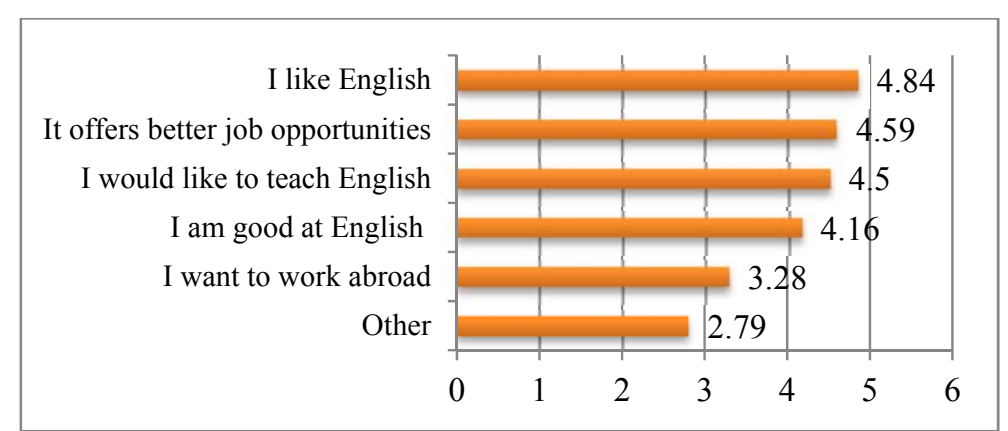

Figure 3. Reasons to choose this specialisation track (average results)

Among the other reasons that move these students to accede to the English foreign language in Primary Education programme is their idea of the wide job opportunities that it offers. It does not seem to be important for the sample whether they have the right aptitudes for acquiring a high competence in all foreign language skills or if their starting point is not the advisable level to study in the foreign language. Therefore, their lack of competence in the language is not an obstacle for them, even when they are conscious that schools require teachers who possess at least a high intermediate level (B2).

\section{Conclusions}

This research paper studies the competence in English of a group of pre-service teachers who are currently involved in the English foreign language Primary Teaching programme at three Spanish universities (by asking them if they have been awarded any official accreditation). The first objective of the paper was to determine their English linguistic competence in order to know if it is adequate or not for their professional needs. The results show that most participants among this group of pre-service teachers do not feel competent in the L2 and they are in need of a higher language level to be successful professionals, as some other researchers have already pointed out (Barrios, 2006; Rubio \& Martínez Lirola, 2010; Rubio \& Martínez Lirola, 2013; Aguilar, 2013; Amengual, 2013; Jover, Fleta, \& González, 2016). Students often think that by following this specialisation they are going to improve substantially their language level. 
Experience shows that intensive practice boosts their command of the language as they follow different courses in the target language in a short time span; however, they do not reach the level they expected, as their expectations are not well grounded. This usually happens with students in low levels $(\mathrm{A} 1, \mathrm{~A} 2)$ who expect to reach a B1 in no time by being registered in the course. The second objective was to define the sample desired English linguistic competence. This group of students are aware of the challenges that primary school English teachers face in their everyday teaching, as they have already observed everyday practice in at least one of their compulsory teaching placement periods. The years of primary education are still fresh on their memory indeed, and they remember the language their teachers used and the amount of vocabulary they were asked to learn in their Science lessons if they participated in any bilingual programme when at school. They realise there is a need for not only a change regarding the methodological approaches used in class, but also a better language command to be able to use the target language in any occasion in class. Most state that their experience as primary language students was poor and that they need to be trained linguistically and methodologically in order to start improving the scenario for generations to come (Barrios, 2014).

The third objective consisted in contrasting both students' accredited —or real- level and that level they think it is sufficient to develop their profession with the professional requirements stated by the different regulations on the matter launched by the different administrations in Spain in order to enter the profession. Here, the students base their answer on their personal beliefs and the higher their language level is, the more demanding they are, on the contrary, the lower their level is, the less demanding they are, although they stress the importance of being trained both in language and teaching methodology. Most would like to finish their university studies achieving a $\mathrm{C} 1$ in the foreign language. Since some of them know they are far from this aim, they continue their English language studies on their own.

There are two important problems here which should be tackled with care by universities or education faculties in the first place but also by the ministry and quality agency, that is, by all stakeholders involved in the process since the degree curriculum is designed to the lecturer who is teaching students at university: students select their specialisation track in English without taking any level test, as it has already been pointed out. Therefore, lecturers may find a mixedlevel class in which they may find students ranging from $\mathrm{A} 1$ to $\mathrm{C} 1 / \mathrm{C} 2$. It would be advisable to have an entry test to guarantee a certain starting level for all students. Likewise, it would be interesting to be able to guarantee a certain level to students who finish their specialisation by passing all exams in every course.

It seems that universities want students to study language on their own, instead of including the study of the foreign language as a compulsory course along the degree. But, at the same time, most universities have created their own language centres which are regularly quite expensive but popular among students.

This idea points out the scarce attention that the new academic programmes pay to linguistic courses. The present study tries to add to the previous literature the need to review the curriculum of this undergraduate programme since it seems to be unsuccessful when preparing 
pre-service teachers adequately according to the current demands of bilingual schools in the whole country.

The limitations of this study include small sample size and statistical unrepresentativeness, but authors understand that the data shown here can shed a little light on the main characteristic features or profile of pre-service English primary teachers in Spain. This contribution has depicted the situation in the field of pre-service training by revealing students' perceptions on their English foreign language level compared to their expectations towards professional linguistic requirements; authors point out that there is a need for more studies with similar characteristics in order to highlight the paramount need to review teacher training programmes, especially those related to foreign language teaching.

\section{Acknowledgements}

The authors would like to thank Dr. Elvira Barrios for her invaluable help in analysing the research data.

\section{References}

Aguilar, A. M. (2013): Competencia comunicativa y norma en los grados de maestro en Educación Primaria. Estudios sobre el Mensaje Periodístico, 19(March), 25-33.

Amengual, M. (2013). Primary Education Degrees in S pain: Do they Fulfil the Linguistic and Pedagogic Needs of Future Teachers? Vigo International Journal of Applied Linguistics,10, 9-27.

ANECA (2005). Libro Blanco. Título de Grado en Magisterio (vol. 1 y 2). Madrid: ANECA. Retrieved from http:/www.aneca.es/Documentos-y-publicaciones/Otros-documentos-de-interes/Libros-Blancos

Barrios, E. (2006). Dificultades y carencias que experimentan y evidencian futuros docentes de inglés durante su intervención docente autónoma en las prácticas de enseñanza. REIFOP, 9(1), 1-12.

Barrios, E. (2014). Creencias sobre el aprendizaje de una lengua del futuro profesorado de inglés de Educación Primaria. Porta Linguarum, 22, 73-93.

British Council (2015). Formación inicial para profesores de programas bilingües en inglés: políticas, prácticas y recomendaciones. Madrid: British Council/Universidad de Alcalá.

Cáceres, L. (2007). Una aproximación al MCER: principales contenidos, aportaciones y consecuencias prácticas. In S. M. Saz (Ed.), Actas del XLI Congreso de la Asociación Europea de Profesores de Español (AEPE). 125 años del nacimiento de Picasso en Málaga (271-282). Málaga: Universidad de Málaga. file:///C:/Users/usuario/Desktop/Capítulo\%20Erasmus/congreso_41_26.pdf

Cores, E. (23 September 2017). El nuevo MCER ya es una realidad [Blog entry]. ReALL: Research in Affective Language Learning. Retrieved from http://reall.es/el-nuevo-mcer-ya-es-una-realidad/

Council of Europe (2001) Common European Framework of Reference for Languages: Learning, Teaching, Assessment. Education Department, Modern Languages Division: Strasbourg. https://rm.coe.int/1680459f97

Council of Europe (2018) Common European Framework of Reference for Languages: Learning, Teaching, Assessment. Companion Volume with New Descriptors. Strasbourg: Education Department, Modern Languages Division. https://rm.coe.int/cefr-companion-volume-with-new-descriptors-2018/1680787989

Fernández-Viciana, A., Barrios, E., \& Ramos-García, A. (2019). Perfil del alumnado de la Mención en Lengua Extranjera (Inglés) en tres instituciones españolas. B. Heinsch, \& N. Rodríguez. (Eds.), Multilingüismo: Innovación y Nuevos Retos. Bern: Peter Lang (in press). 
García Santa-Cecilia, A. (2003). Bases comunes para una Europa plurilingüe: Marco común europeo de referencia para las lenguas: aprendizaje, enseñanza, evaluación. Tarbiya: Revista de investigación e innovación educativa, 33, 5-48.

Jover, G., Fleta, T., \& González, R. (2016). Pre-service education of primary school teachers in the context of foreign language bilingual teaching. Bordón, 68(2), 121-135, doi:10.13042/Bordon.2016.68208

Mearns, T. (2012). Using CLIL to enhance pupils' experience of learning and raise attainment in German and health education: A teacher research project. The Language Learning Journal, 40(2), 175-192.

Ministerio de Educación (2011). Programa Integral de Aprendizaje de Lenguas Extranjeras, 2010-2020. Retrieved from https://www.campuseducacion.com/files/programa-integral-aprendizaje-lenguas-ce-23-03-11.pdf

Ministerio de Educación y Ciencia (2007). Orden ECI/3857/2007, de 27 de diciembre, por la que se establecen los requisitos para la verificación de los títulos universitarios oficiales que habiliten para el ejercicio de la profesión de Maestro en Educación primaria. Boletín Oficial del Estado, 312, 53747-53750. Retrieved from https://www.boe.es/eli/es/o/2007/12/27/eci3857

Ministerio de Educación, Cultura y Deporte (2002). Marco Común Europeo de Referencia para las Lenguas: aprendizaje, enseñanza y evaluación. Madrid, Secretaría General Técnica del MECD. Retrieved from http://cvc.cervantes.es/ensenanza/biblioteca_ele/marco/cvc_mer.pdf

Ramos, A. M. (2008) El Espacio Europeo de Educación Superior (EEES) y el Sistema Europeo de Transferencia de Créditos (ECTS). En A. Rodríguez, M. J. Caurcel y A. M. Ramos (coords.) Didáctica en el Espacio Europeo de Educación Superior: guías de trabajo autónomo. (11-44). Madrid: Eos.

Rubio, F. D., \& Martínez Lirola, M. (2010). English as a foreign language in the EU. Preliminary analysis of the difference in proficiency levels among the member states. European Journal of Language Policy, 2(1), 23-39.

Rubio, F. D., \& Martínez Lirola, M. (2013). ¿Qué pasa en España con el inglés? Análisis de los factores que inciden en el éxito del aprendizaje. In M. P. Díez, R. Place, \& O. Fernández (Eds.), Plurilingualism. Promoting Cooperation between Communities, People and Nations (pp. 143-149). Bilbao: Universidad de Deusto.

Ruiz Cordero, M. B. (2016). La práctica y formación docente del profesorado de lengua inglesa en Castilla La Mancha. Encuentro, 25, 102-117. 